\title{
転移性肺腫瘍の原発巣の鑑別を要し組織所見を経時的に観察し得た 肺癌・直腸癌の重複癌の症例
}

\author{
伊藤 悠 1 伊藤 優 1 川川島英俊 $1 \cdot$ 山本健嗣 $2 \cdot$ \\ 金子 猛 $3 \cdot$ 角田幸雄 $4 \cdot$ 前原孝光 2
}

\section{A Case of Multiple Cancers of the Lung and Rectum Requiring Differentiation of the Primary Lesion of Metastatic Lung Tumors and Exhibiting Histological Changes Caused by Treatment During the Course}

\author{
Haruka Ito1; Masaru Ito1; Hidetoshi Kawashima1; Taketsugu Yamamoto2; \\ Takeshi Kaneko3; Yukio Kakuta4; Takamitsu Maehara2 ${ }^{2}$ \\ ${ }^{1}$ Department of Respiratory Medicine, ${ }^{2}$ Department of Thoracic Surgery, Yokohama Rosai Hospital, Japan; ${ }^{3}$ Department of \\ Pulmonology, Yokohama City University Graduate School of Medicine, Japan; ${ }^{4}$ Department of Pathology, Yokohama Rosai \\ Hospital, Japan.
}

ABSTRACT - Background. When metastatic pulmonary nodules are found in patients with multiple primary cancers, then making a histopathological diagnosis is important in order to make accurate treatment decisions. We diagnosed a patient with multiple cancers of the rectum and lung cancer. After performing partial thoracoscopic lung resection, we histopathologically evaluated the changes over time as well as the histopathology of the metastatic lesions. Case. A 63-year-old woman was found to have left upper lobe lung cancer, rectal cancer, and multiple metastatic lung nodules in the right lung at the time of the initial examination. The rectal tumor was judged to be of an early stage. We thus considered that the patient's lung cancer should be treated first and thus administered afatinib. Thoracoscopic right lower lobe partial resection was performed to determine the diagnosis and guide the treatment decisions. The histological diagnosis was lung metastasis of rectal cancer. Laparoscopic rectal resection was performed. Since a marked reduction was observed in the size of the left lung tumor, radical lung resection was performed and afatinib was terminated. Subsequently, multiple metastatic nodular shadows were found again in the right lung, and thoracoscopic right partial lung resection was performed for diagnostic purposes. Metastasis of lung cancer was detected in two of the six biopsy sites; metastasis of rectal cancer was detected at the other sites. Conclusion. The early diagnosis of metastasis is important for guiding treatment decisions. Physicians should take care that they not miss the opportunity to resect the primary lesion.

KEY WORDS — Lung cancer, Rectal cancer, Double cancer

(JJLC. 2020;60:109-114)

Corresponding author: Masaru Ito.

Received September 19, 2019; accepted January 8, 2020.

要旨——背景. 重複癌の症例では多発転移性肺結節影 を認めた場合，治療方針決定のため転移巣の組織診断が 必要となる。我々は, 直腸癌と肺癌の重複癌を認め, 多 発肺結節影に対し複数回胸腔鏡下肺切除術を行い, 転移 巣の組織診断に加えその組織所見を経時的に観察し得た 症例を経験した. 症例. 63 歳女性. 左上葉肺癌と直腸癌 があり，右肺に転移性肺結節影を認めていた。直腸癌は
早期癌と判断され肺癌治療先行の方針とし, アファチニ ブの投与を開始した。左肺上葉の原発巣は縮小が認めら れたが，右肺結節影は増大が認められた。診断と治療方 針決定のために胸腔鏡下右肺下葉部分切除術を施行し, 右肺結節影は直腸癌肺転移の診断となった。直腸癌に対 する腹腔鏡下直腸切除術施行後に, 左肺癌に対して根治 的肺切除術を施行しアファチニブ投与を終了した。その
横浜労災病院 1 呼吸器内科, 2 呼吸器外科 ; 3 横浜市立大学大学院 医学研究科呼吸器病学; 4横浜労災病院病理診断科.
論文責任者：伊藤 優.

受付日：2019 年 9 月 19 日，採択日：2020 年 1 月 8 日. 
後再び右肺に多発転移性結節影の出現を認め, 診断目的 に胸腔鏡下右肺部分切除術を行った。 6 ケ所の生検部位 のうち 2 ヶ所は肺癌からの転移であったが, 残りは直腸 癌からの転移の所見であった。結論．重複癌では治療方
針決定のため早期に転移巣の組織診断を行い，原発巣の 切除術の時期を逸しないように留意すべきであると考え られた。

索引用語——肺癌, 直腸癌, 重複癌

\section{はじめに}

重複癌の診療において転移性肺多発結節影を認めた場 合，組織診断が重要となり治療方針に関わる。今回我々 は肺癌及び直腸癌の重複癌の多発肺転移を経験し, EGFR-TKI による治療を行った．経過中に初診時を含め 複数回外科的な組織採取を行い, 特に多発肺結節影に対 しても全ての箇所の切除を行い，肺癌及び直腸癌の転移 が混在していることがわかった.
重複癌の治療方針を検討する上で教訓的な症例であっ たため，報告する，

\section{症 例}

症例 : 63 歳, 女性.

現病歴 : $\mathrm{X}$ 年 11 月, 健診で胸部異常陰影を指摘され た. 胸部 CT で左上葉に腫瘍影と右下葉に結節影を認め (Figure 1A，1B），経気管支肺生検で左上葉の病変は肺 腺癌と診断された。PET-CT で直腸に集積立進が認めら
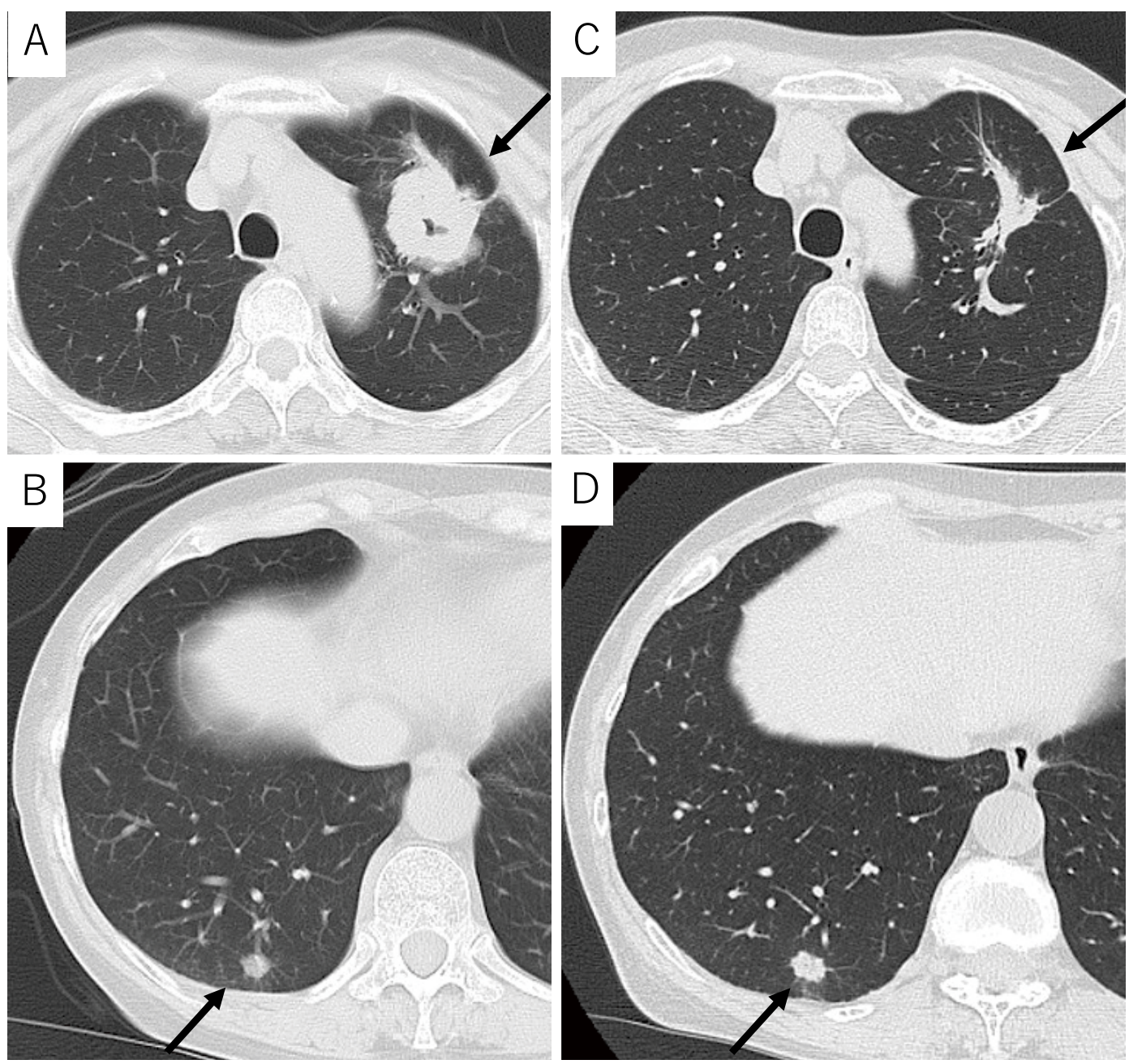

Figure 1. The clinical course of the chest CT findings. (A) Chest CT showed a 35-mm tumor in the left upper lobe. (B) A nodule in the right lower lobe. (C) Two months after the initiation of afatinib, the primary lesion had decreased in size. (D) In contrast, the nodule had increased in size. 

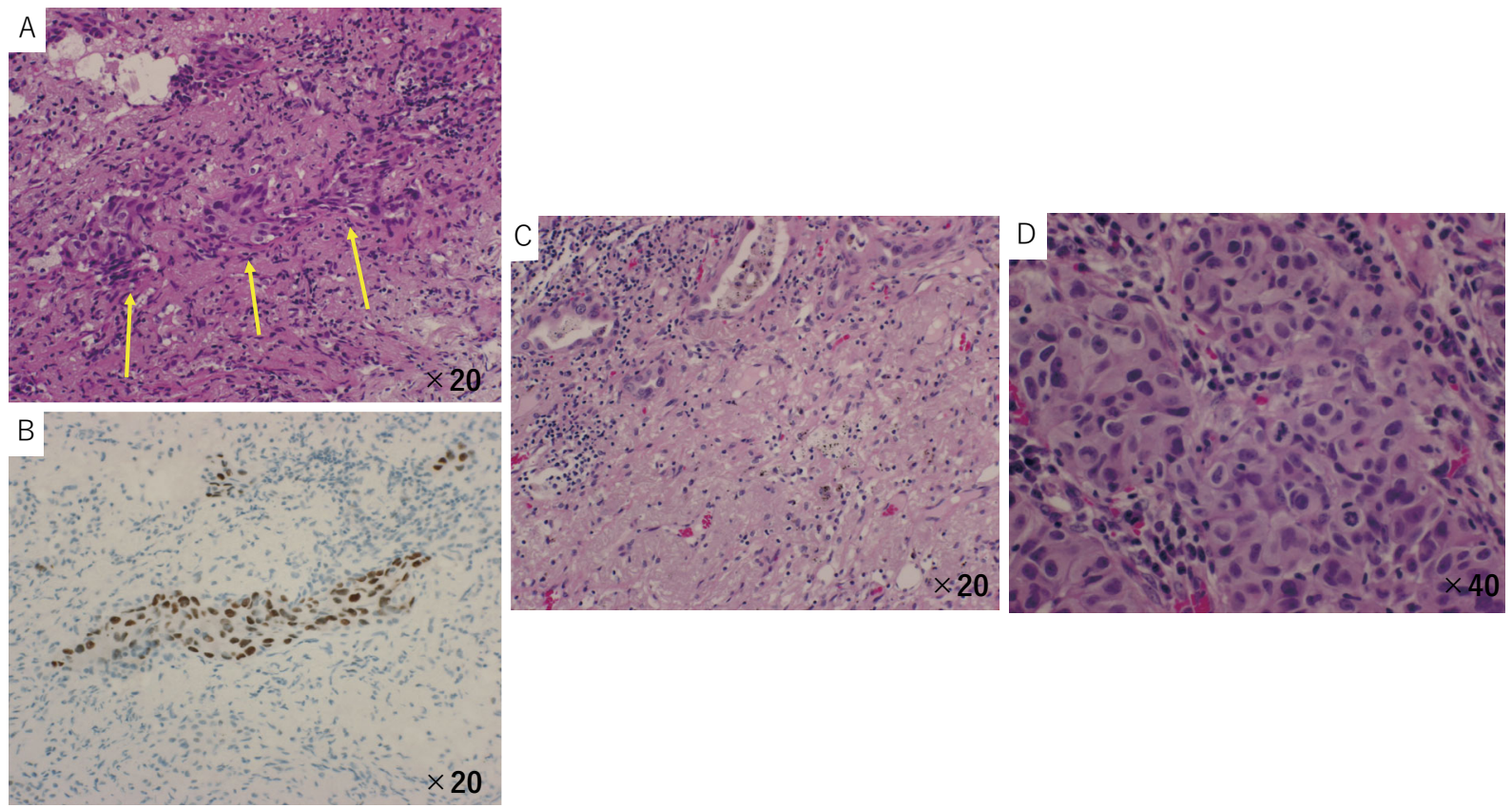

Figure 2. Histological features of the biopsy specimens. (A) The initial examination was performed by a bronchopulmonary biopsy. Atypical cells were observed. These nuclei were swollen more than twice (arrows). B) Immunohistochemical staining was positive for p53. (C) Five months after the initiation of afatinib. The surgical specimen was observed to have been replaced by fiberization. (D) The surgical specimen at the time of the recurrence of lung cancer and rectal cancer. Histological findings of the metastatic tumor from lung cancer. Areas of poor differentiation were observed with marked nuclear pleomorphism, large nucleoli, and nuclear inclusions.

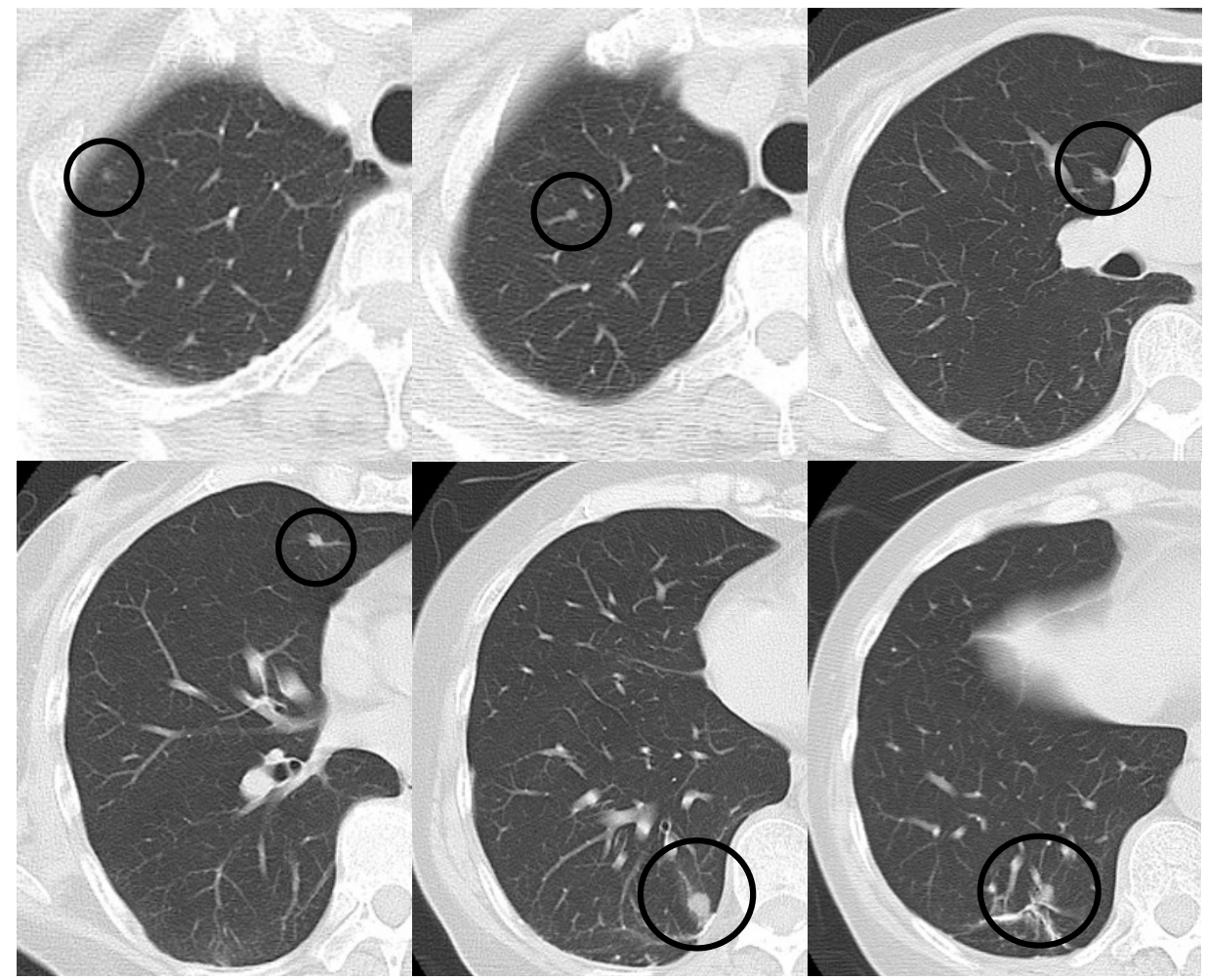

Figure 3. Chest CT showed multiple metastatic lesions in the right lung. 


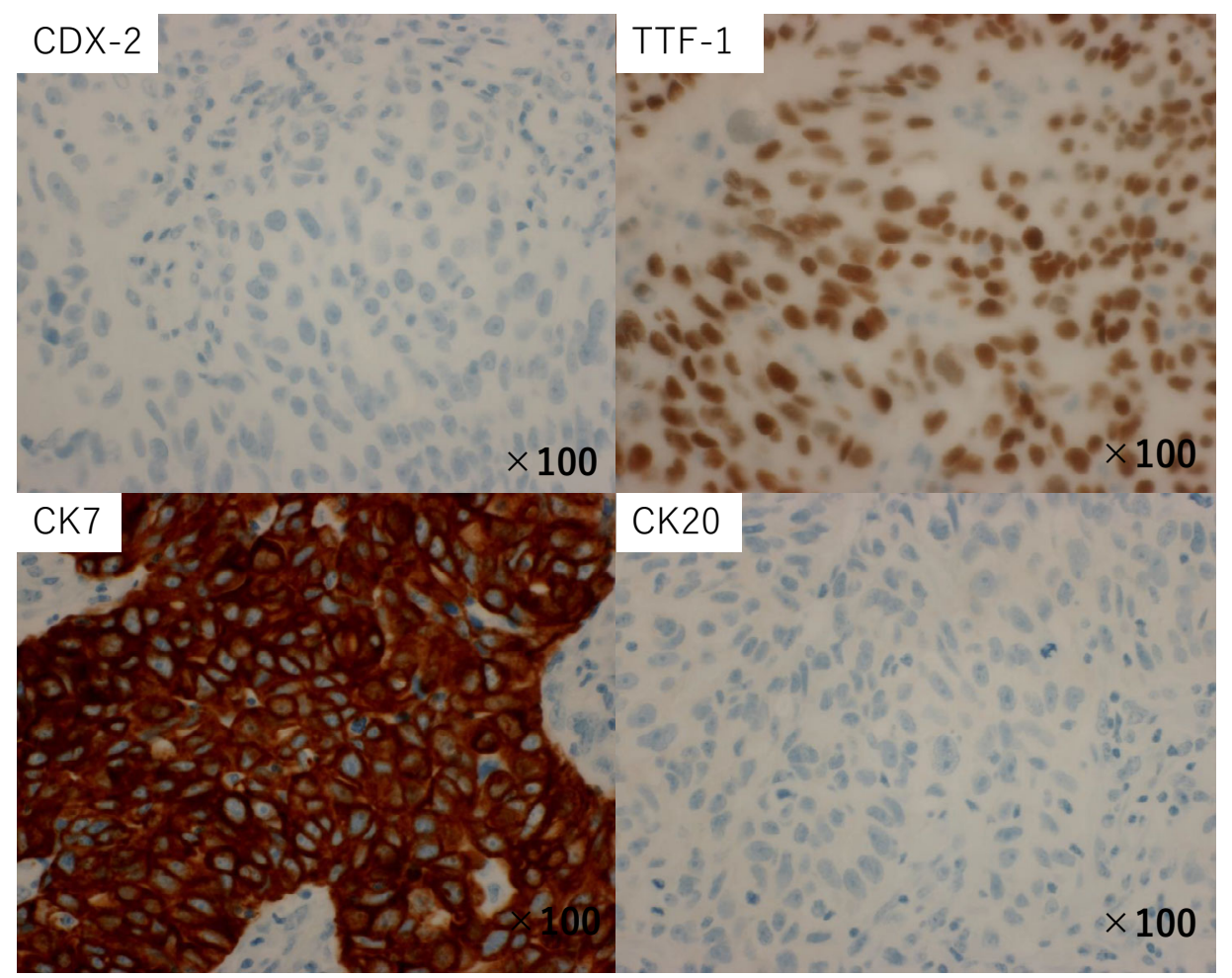

Figure 4. The immunohistochemical findings of the metastatic tumor from lung cancer. Immunohistochemical staining was negative for CDX-2, positive for TTF-1, positive for CK7, and negative for CK20.

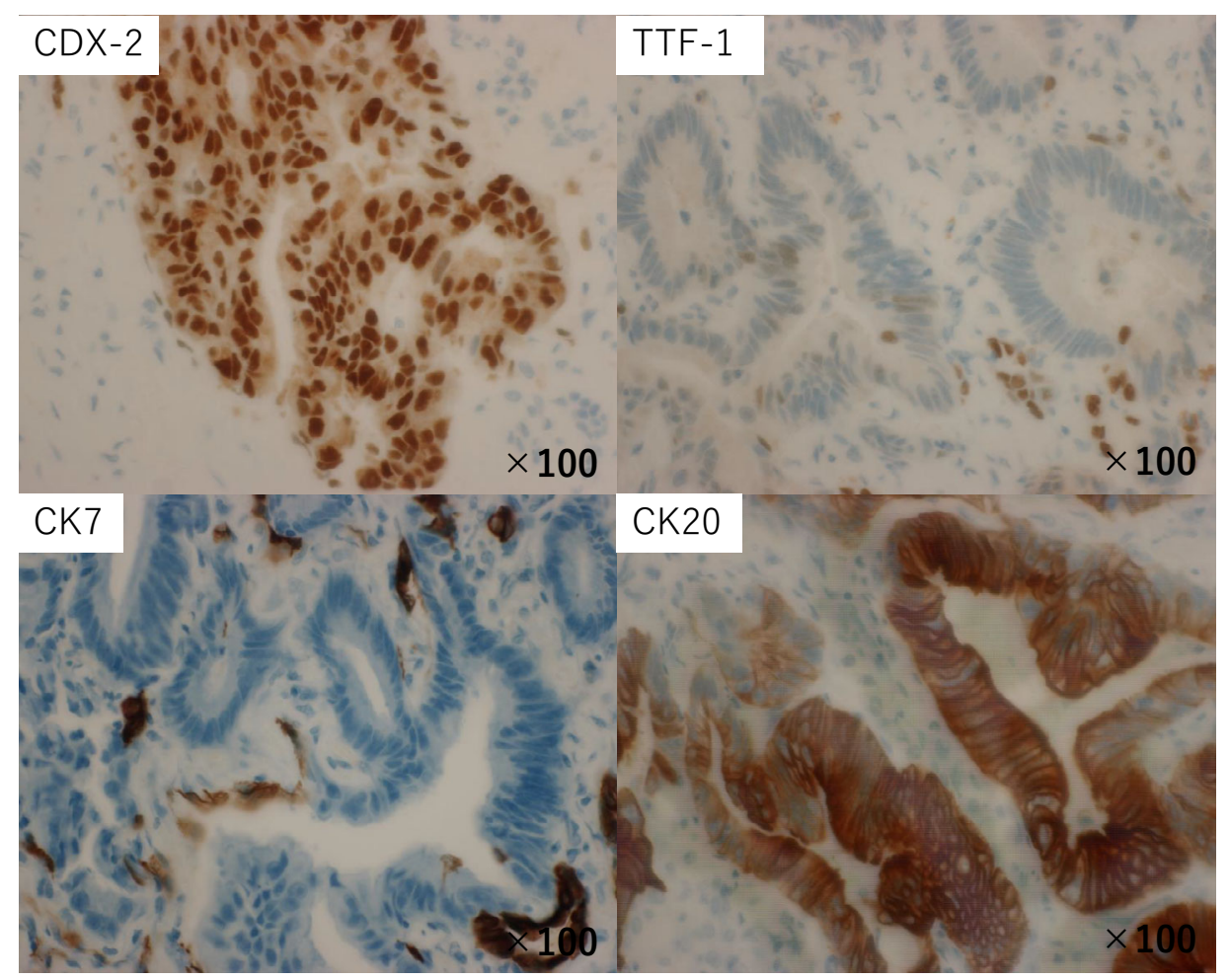

Figure 5. The immunohistochemical findings of the metastatic tumor from colon cancer. Immunohistochemical staining was positive for CDX-2, negative for TTF-1, positive for CK7, and negative for CK20. 


\section{afatinib}

\section{afatinib}

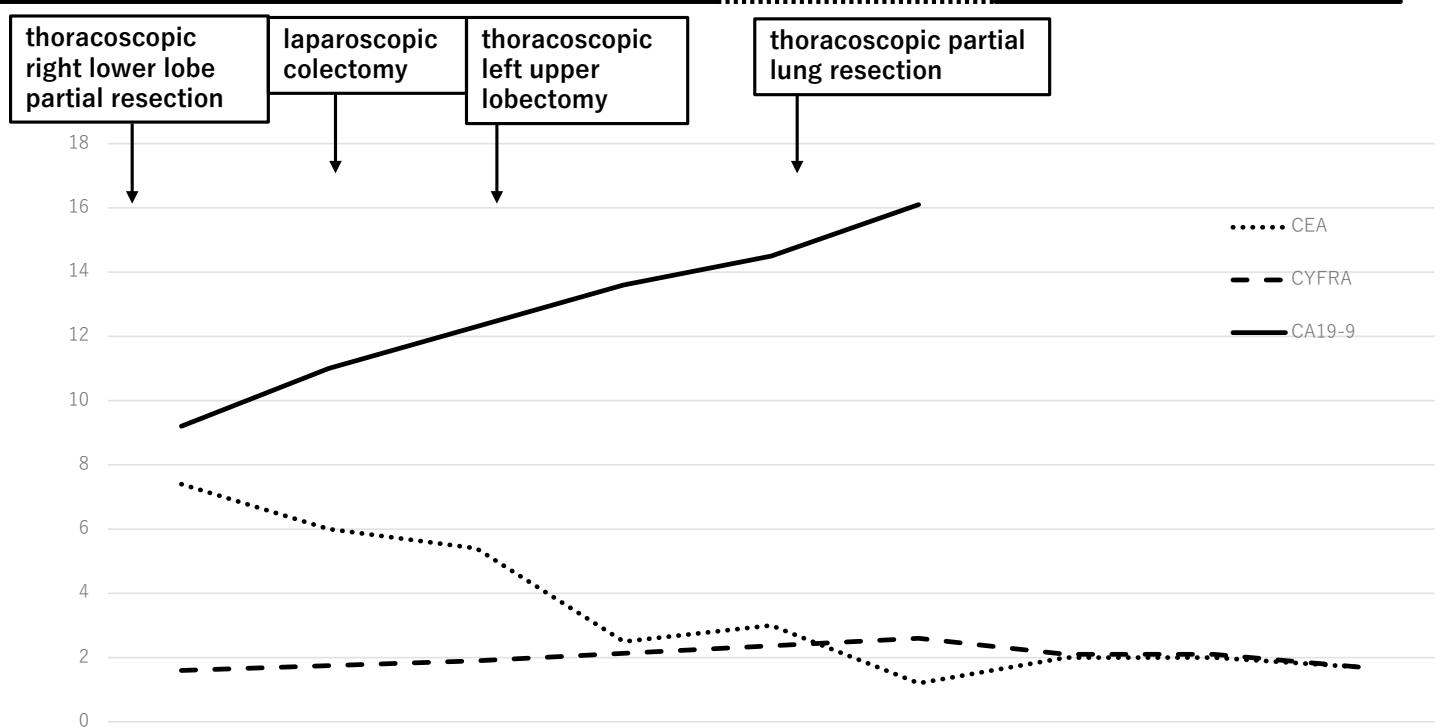

2018.5

$2018.6 \quad 2018.7$

2018.11

2019.2

Figure 6. The clinical course of the patient's tumor marker levels.

れたため下部内視鏡検査を施行し, 粘膜下層への浸潤を 認め, 病理学的に高分化型管状腺癌と診断された。直腸 癌の深達度は早期であると評価されたため右肺の結節影 は左肺癌からの転移巣と判断し, 切除不能の進行肺腺癌 cT2aN0M1a, stage IVA (EGFR 遺伝子変異 Del 19 陽性) の診断で肺癌の治療を優先する方針となり, $\mathrm{X}+1$ 年 2 月に当科入院となった.

既往歴：虫垂炎 (20 歳).

生活歴：喫煙 15 本 $/$ 日 $\times 38$ 年間.

家族歴：特記事項なし.

職業歴：飲食業.

身体所見：身長 $156 \mathrm{~cm}$, 体重 $52 \mathrm{~kg}$, 意識清明，体温 $36.1^{\circ} \mathrm{C}$, 血圧 $119 / 71 \mathrm{mmHg}$, 肺音清, 心音純. その他に 特記事項なし.

検査所見：胸部 CT (Figure 1A，1B）では左上葉に辺 縁不整, 周囲の引き込み像を伴う $35 \mathrm{~mm}$ の腫瘤影を認め た。右下葉に転移を疑う円形の結節影を認めた.

入院後経過 $: X+1$ 年 2 月よりアファチニブの投与を 開始した.アファチニブ投与後左上葉の原発巣は縮小を 認める一方で右肺結節影は増大を認め（Figure 1C，1D）, 異なる治療効果を呈していたことから, 診断・ 治療方針の決定のために X+1 年 4 月に胸腔鏡補助下右 肺下葉部分切除術を施行した. 右肺の結節影は組織学的 に直腸癌の肺転移の診断となり (Figure 2$), \mathrm{X}+1$ 年 6 月に直腸癌に対し腹腔鏡下直腸切除術及びハルトマン術
を施行した(pT1bN0M1a p-stage IVA)。肺癌の臨床病期 分類を cT2aNOM0 stage IB と修正し， 7 月に原発性肺癌 に対して胸腔鏡補助下左肺上葉切除術を施行した。肺癌 の病期は stage IB であり術後よりアファチニブは終了 した，その後定期的に経過観察を継続していたが，X+1 年 11 月の CT 検査で右肺に新規多発結節影を認めた (Figure 3). 診断・治療目的に同月胸腔鏡補助下右肺部 分切除 $\left(\mathrm{S}^{1}, \mathrm{~S}^{2}, \mathrm{~S}^{3}\right.$, 下葉の 3 ケ所) が施行された. 6 ケ 所の外科的生検部位のうち 2 ケ所は肺癌の転移 (Figure 4)であり, 残りは直腸癌の転移の所見であった（Figure 5).アファチニブを再開し現在も経過観察中である (Figure 6).

\section{考 察}

重複癌において多発肺転移を認めた場合，治療方針の 決定が困難であることは少なくない．本例では直腸癌の 壁深達度が $\mathrm{T} 1 \mathrm{~b}$ であり, 右下葉の結節影については当初 は大腸癌からの転移よりも肺癌の対側転移の可能性が高 く肺癌が予後規定因子と判断されたため, 肺癌治療を先 行する方針となった。稀ではあるが早期直腸癌でも遠隔 転移を認めた症例報告はあり,1 本例の直腸の手術検体 では血管侵襲とリンパ管侵襲を認めており，血行性に肺 転移を生じた可能性がある。一臓器への単発転移であり, 適切な治療方針の決定のために当初より組織学的診断を 考慮すべきであったという点で教訓的な症例であった. 
肺転移を有する大腸癌では，肺転移巣に対する手術選 択は長期生存・治癒を目指す上で有効な治療選択と考え られている. 大腸癌研究会プロジェクト研究で行われた 多施設集計では, 肺切除例の 5 年生存率は $46.7 \%$, 非切除 例の 5 年生存率は $3.9 \%$ で, 肺切除後の残肺再発でも 20〜 $48 \%$ の 5 年生存率が報告されている. ${ }^{2}$ 肺転移を有 する大腸癌の手術適応については, 大腸癌治療ガイドラ インでは, 3 肺転移に対する切除の適応基準は, (1)耐術可 能, (2)原発巣が制御されているか制御可能, (3)肺転移巣 を遺残なく切除可能, (4)肺外転移がないか制御可能, (5) 十分な残肺機能，が基準とされており，本例では 2 回目 の胸腔鏡補助下右肺部分切除術は上記適応を満たすと判 断された. 本例では, 原発性肺癌は先行投与を行ったア ファチニブで縮小が得られ病勢がコントロールされてい ると判断されて大腸癌原発巣に対する手術を優先した が, 当初より右肺転移巣が直腸癌からの転移と判明して いた場合, 直腸癌と肺癌の手術のいずれを優先するかの 判断は難しい.

本例では初回診断時を含め計 4 回肺より組織採取を 行った。これらの組織所見を経時的に観察し得た（Figure 2). アファチニブ投与前の経気管支肺生検検体 (Figure 2A，2B）は核腫大を伴った異型細胞を認め, p53 陽性であった７月の左肺上葉切除検体では（Figure 2C), 治療に伴い腫瘍細胞はほとんどが消失し線維組織 に置換されていた. $\mathrm{X}+1$ 年 11 月の右肺多発結節影の部 分切除検体 (Figure 2D) では計 6 ケ所生検を行ったが, 肺癌と直腸癌のどちらの転移かが鑑別となり TTF-1 陽 性, CDX-2 㓌性, CK7 陽性, CK20 㓌性であることから これら 2 ヶ所が肺癌の転移と診断し (Figure 4), 残り 4 ヶ所が直腸癌の転移（Figure 5) と診断した。肺癌の転 移巣は, 分裂像も散見され分化度が低く高度な異型を 伴った組織像を呈していた. 初診時と同様に EGFR 遺伝 子変異 Del 19 陽性が確認されたが, T790M 変異は認め られなかった，気管支鏡下肺生検での検体と手術検体で は採取し得る標本の大きさが異なるため比較は困難では
あるが，経過中に分化度が低くなっていった可能性が考 えられた。経時的に組織所見の観察を行い検討した文献 報告は少ない. 細田らの報告4によると, 治療により変性 を示した遺残癌の所見としてクロマチンが濃縮し空胞状 の胞体を保持し, 異型の立進した大型の癌細胞が認めら れることが多いとされている．治療前は高分化肺腺癌で あったがチロシンキナーゼ阻害薬を投与後胸壁再発の組 織像において細胞異型が立進した低分化腺癌の像に変化 している症例が報告されているが, 4 T790M 点変異が 確認された点が本例とは異なっていた.

\section{結 論}

複数科で集学的な手術・治療を行った重複癌の症例を 経験した. 重複癌の本例において, 多発肺結節の生検の 際 1 ケ所のみの部分切除でなく複数結節を部分切除し組 織学的に検討したことは，その後の治療方針を正しく検 討する上で有意義であったと考えられた．重複癌の診療 においては画像検査を含めた定期的なサーベイランスを 行い, 長期生存・治癒を目指し時期を逸することなく治 療選択ができるよう留意すべきであると考えられた。

本論文内容に関連する著者の利益相反：なし

謝辞 : 病理組織学的検討を御担当いただきました横浜労災病 院病理部長谷川直樹先生に深謝いたします.

\section{REFERENCES}

1. 朝山直樹, 永田信二, 鴫田賢次郎, 青山大輝, 福本 晃, 金子真弓, 他. 遠隔転移再発を認めた PG type 隆起型下部 直腸 $\mathrm{T} 1 \mathrm{~b}$ 癌の 1 例. 胃と腸. 2019;54:914-920.

2. 大腸癌研究会, 編集. 大腸癌治療ガイドライン. 医師用 2019 年版. 東京：金原出版；2019:26.

3. 大腸癌研究会, 編集. 大腸癌治療ガイドライン. 医師用 2019 年版. 東京：金原出版；2019:61.

4. 細田和貴, 堀尾芳嗣, 谷田部恭. 肺癌の治療による病理組 織学的変化. 病理と臨床. 2008;26:459-465. 